\title{
Study of chemical qualities of raw buffalo milk at different milking times
}

\author{
U.K. Shukla and Arvind Shukla
}

\begin{abstract}
To study of chemical qualities of raw milk of buffalo was conducted at chitrakoot satna (M .P.) the objective was to find out the chemical quality of buffalo's on fat, protein, lactose ash water, sp, gr., S.N.F. and T. S. compositional quality of raw milk and under full hand diagonal method of milking at mini dairy farm statistical analysis applying the technique of analysis of variance (f-test) the most widely used method for determining protein content by kjeldahi method for nitrogen determination since nitrogen is a characteristic element in protein by its accurate determination protein characteristic can be finding animal showed considerable variation regarding the principal components in milk. Results presented above, that the chemical quality of raw buffalo milk at morning $\left(\mathrm{M}_{1}\right)$ was found best in terms of maximum protein (\%), specific gravity (cc), fat (\%), lactose (\%), total solid $(\%)$ and solid not fat (SNF) (\%) and minimum ash (\%) and water (\%); followed by evening milk $\left(\mathrm{M}_{3}\right)$ and noon milk $\left(\mathrm{M}_{2}\right)$.
\end{abstract}

KEY WORDS : Raw milk, Chemical quality, Buffalo milking, Times

HOW TO CITE THIS PAPER : Shukla, U.K. and Shukla, Arvind (2019). Study of chemical qualities of raw buffalo milk at different milking times. Res. J. Animal Hus. \& Dairy Sci., 10(1) : 1-13 : DOI: 10.15740/HAS/RJAHDS/10.1/1-13. Copyright@ 2019: Hind Agri-Horticultural Society. 